NOTES ON MR. HENSLEIGH WEDGWOOD'S DICTIONARY.

тà Bpómara. "Meats were created for the belly" (to feed it).

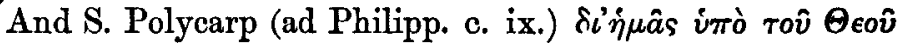
àvartávтos. "Raised by God from the dead for our sakes," (to justify us).

S. Justin, M. Apol. i. 10., ii. 5.

To sum up, $\delta \iota a ́$ is sometimes used to introduce either-

1. The Final Cause itself, or

2. The object of the Final Cause whether or no an explanatory clause follows.

The Final Cause (or its object), being antecedent in idea to the action ëveкá $\tau o v$, is confused with and treated as an Antecedent Cause. Hebrews ix. 15, may be cited as giving an example of the difficulty which this confused use of $\delta i a$ occasions, where it is I think uncertain

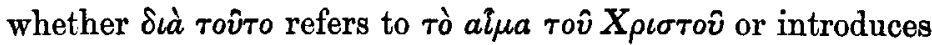
the of $\pi \omega$ s clause following. Surely, Winer at least is wrong in not giving a more formal recognition to this use of $\delta \imath a ́$.

\title{
XIII.-NOTES ON Mr. HENSLEIGH WEDGWOOD'S DICTIONARY OF ENGLISH ETYMOLOGY, AND ON SOME WORDS NOT DISCUSSED BY HIM. By G. P. Marsh.
}

Is an American edition of Mr. Wedgwood's first volume, I ventured to comment on some of his derivations, which were either not satisfactory to me, or to which I was able to add additional illustrations. The edition referred to is not to be continued; but I have made a few notes on words treated by Mr. Wedgwood in the second and third volumes of his valuable work, as well as on other words not examined by him. At the request of the Honorary Secretary of the Philological Society, these notes are now offered, with apologies for their fragmentary nature, to the consideration of $\mathrm{Mr}$. Wedgwood, and the members of the Society. 


\section{WEDGWOOD, vUL. II.}

P. 11. Empeach.-The earliest sense of this word, as well as of the M.L. impechiare and impetere (see Du Cange), appears to be that of accusing. If the Latin peccare is not the root, did it not at least influence the form of this word, in analogy with Fr. pecher?

P. 18. Equerry. - See Littré, Dict. F. Ecurie. But, after all, is it clear that M.L. equaria (see Du Cange) has nothing to do with this word?

P. 48. Filch.-In old Portuguese we have filhar allied to Ital. pigliare, and perhaps Fr. piller.

P. 50. Find, in the sense of to provide food and lodging, as, A B works for so much a month and finds himself. See a like example in Rob. Glouc., p. 373, note. Is this the same word?

P. 54. $F i x$, in the "American" sense. There is an example of this use in Dampier (ed. of 1703) vol. ii., p. 5 .

Pp. 54, 65, 70. Flesh, fitch-Are not these different forms of the same word?

P. 62. Fleam: a lancet. The proposed derivation from famma, though plausible, is contrary to historical evidence, which clearly identifies this word with the Græco-Latin phlebotomum. There can be no doubt that the Eng. fleam and the Duteh vlieme are the same word, and that both are different forms of the M.H.D. vliedeme, fliedm, fleidme, fietemen, fitte, ete., as to which see Müller and Zarncke, M.H.D. Wörterbuch, under vliedeme, vol. iii., p. 341 . These words are evidently from the M.L. flebotomum, which occurs in many forms in mediæval literature, both Latin and Romance. The following examples I take from the Trattati di Mascalcia, Bologna, 1865 :-Tolli la febochomia, cioè lancietta, p. 73. Nel principio di questa infermita faebochoma la vena,; vena febochomata; poscia fiebochoma, p. 83. Allora fa aprire il male collo fiebochoccio o lancietta, p. 85 . Accipe foctumum et fac cum ipsâ aliquantula foramina in pelle, p. 171. Fiebotomare, p. 279. Most of the transitional 
forms will be found collected in Diefenbach, Sup. Du Cange, (Glossarium Latino-Germanicum), 1857, under Flebotomum.

P. 66, Flew, and p. 76, fog.-Fiocca is a very common word for snow, especially drifted snow, in the dialects of N. Italy.

P. 68. Fling, etc.-To flense is, in the dialect of the whale fishery, to strip the flesh and fat from the carcase of the whale.

P. 109. Fur.-In Old N. grávara (gen. grávöru) is a species of fur. This word, in Danish, under the influence of the Ger. Pelzwerk, has become Graavark; but is not vara the the same word as fur, and the resemblance between fur and fodder accidental ?

P. 120. Gallant.-This word, at least in the combination "lusty gallant," meant bright red or scarlet. See Holland's Pliny, ix. 41 ; Holinshed, i. 290 ; Purchas's Pilgrims, i. 199 ; St. Palaye, i. 292. I suspect a connection between this word in one, if not all, of its meanings, and the Latin gallus, through the Italian. Cantù, Sull' Origine della Lingua Italiana, p. 119, cites from Odo delle Colonne (A.D. 12501300) these lines-

E sarò fuor di pene

$\mathbf{S}$ arrò allegrezza e gallo-

where gallo evidently signifies joy, pleasure, exultation. Gallare d'allegrezza, ringalluzzare, and ringalluzzire are still used for to strut, to swell with pride or triumph, or, as we say, to be cock-a-hoop; and there can be no doubt that the last two verbs are from gallo, a cock, though gallare may be from galla, a gall-nut, an acorn, a light nut. The cock has red wattles, comb, and often plumage, and hence, probably enough, the sense of red, scarlet, formerly ascribed to gallant.

P. 186. Grout.-Among masons this word is used to signify a fluid mortar, employed to fill the interstices between broken stone in foundations, and joints in masonry. See Glos. of Architecture. This may be a secondary meaning, but, if so, it seems to have quite superseded the primitive sense.

P. 199. Haberdasher.-Is there any authority for the strange word hapertask as Old Northern? [Haldorson]. 
P. 214. Harangue : O.F. raison, M.L. ratio.-Mr. Wedgwood's derivation is ingenious and apparently well made out, but the force of the argument is weakened, if not destroyed, by the admission that the It. aringare is "the origin of F. harangue." The assumption that Fr. "aregnier was converted into It. aringare" is a pure conjecture, and an improbable one. Nor is it in the least likely that the M.L. ratio was ever changed into aringare by a direct series of mutations, without the intervention of the French; for, I think, no case can be cited where the L. or M.L. -atio has become -ingo in Italian. On this point, consult any Italian rhyming dictionary, where the words with this ending are collected. Such a derivation, though etymologically improbable, might be admitted if supported by historical proof; but historical evidence is to the contrary, and the meaning originally aseribed to the noun aringo, whence the verb aringare, is irreconcilable with the supposition that it comes from ratio.

In the earliest examples eited by Tommaseo, Nuovo Dizionario, s. v. Aringo e Amingo, the word means giostra, duello, etc., or steccato, torneo, the lists for jousting, the race or racecourse, all of which suggest the German ringen or Ring. Later, it came to mean a pulpit or balcony, synonymously with ringhiera; and I find that some Italian scholars believe this last, as an architectural term, to be the origin of aringare, to harangue, because the people were often addressed from a balcony. At present, aringo has the sense of career, as, aringo politico, perhaps more frequently than any other meaning, and this, of course, comes from the notion of joust or tournament. The multitude of M.L. forms of this word found in Du Cange countenance sometimes Wedgwood's etymology, sometimes the German Ring, through aringo, as the source. I think we may be justified in treating the resemblance between It. aringare and Fr. haranguer as accidental, and this disturbing element being eliminated, Mr. Wedgwood's derivation might stand good.

P. 239. Higre, Eager, Aker.-I believe this is the Old Northern agir, the sea, the flow of the sea, the name of a sea-god personifying the sea as a destructive agency. 
P. 245. Hoary-What is the meaning of hore in the O.E. holtes hore? Is hore, here, leafy, from the resemblance of the crown of a tree in leaf, to a head of hair?

P. 357. Lord.-The compound lag-var $8 r=$ law-maintainer, is a possible etymology of the O.N. lávar $\succ r$, though hlaford can hardly be a similar compound.

P. 361. Lukewarm. - The first element in this word appears to be allied to the Dan. lunken; Swed. ljumm.

P. 486. Pare.-I am not sure that the historical order of derivation in the phrase to pare an apple, and the like, is not here inverted. Biblesworth, Nat. Antiq., p. 150, uses parture for the skin of an apple. Thence, to pare, may be to skin the fruit. So of paring bread. Biblesworth, same rol., p. 172, and see English examples in note.

P. 518. Pipkin may be a diminutive of pig, Sc. an earthen vessel, and if so, is the same word as piggin.

P. 522. Place.-Platea, Lat. from Gr. $\pi \lambda a \tau$ v́s, seems a more probable derivation (see Platea in Du Cange) at least for place in the sense of a wide street or square.

P. 529. Plough.-In the dialect of Brescia, piò is both a plough and a land-measure $=\cdot 779$ of an acre.

P. 536. Pompion, pumpkin. - Is the latter word anything more than a vulgar pronunciation of the former? A tompion in ships of war was formerly, and perhaps still is called by the sailors a tunkin, or tompkin.

P. 550. Provender.-D'Esclot, in Buchon, Chroniques Etrangères, p. 700, has : Si y ha prou vianda, e sis pot stablir mig any de la vianda que y es, etc. Prou vianda is sufficient provisions, and vianda is doubtless from vivere, Lat.

P. 552. Pry.-This word is very commonly used in the U.S. for prise, to force open by leverage. To pry into a sceret, etc., I believe to be the same word.

\section{WEDGWOOD, voL. III.}

P. 10. Queer.-As this word is used by Gawin Douglas in a passage eited by Richardson, in the sense of bad, perverse, it may be considered as belonging rather to the Scottish than to the slang dialect; and all the meanings assigned to it 
may be deduced from the German quer. The corresponding Danish tvar is used both adverbially and adjectively, and as an adjective it signifies perverse. There can be no doubt that Ger. quer, and Dan. tvar, are etymologically connected, and both very probably, as is suggested by Wachter in regard to the former, with Celtic gwyr, gwyrog, guyro. I am also inclined to suspect that our English across, generally explained as on cross, is from the same root, which better suits the meaning, unless, indeed, we suppose an allianco between Lat. crux and Ger. quer. Palsgrave, p. 829, col. a, gives agars as the French equivalent for a katerwavyng. The verb to cut, catering, is in common use in New England in the sense of cutting cloth, etc., obliquely across; and Halliwell has "2. Cater, to cut diagonally, var. dial," which is doubtless the meaning of Palsgrave's a katerwavyng. Agars, then, meant much the same as across, and may be the immediate source of the latter word. Agars may be connected with either the Celtic or the Teutonic words cited above, and very probably with both.

The fact that none of the Romance dialects express the ordinary meaning of across by any word derived from crux, is entitled to some consideration; and it may be added that Dan. Korsvei, Ger. Kreuzweg, and the other compounds of Kors, Krenz, are only applied to cases where two roads, or other objects similar to each other, cut each other transversely.

P. 23. Rack, 3rd sense, as hay-rack.-The Danish Rakke, a row or series, seems to suggest a not improbable origin for rack in this sense.

P. 40. Ransuck.-The O.N. rán, the act of plundering stolen goods, booty, is a probable source of the first element in Icel. and Sw. ransaka, to search for stolen goods.

P. 84. Robe.-As an illustration of the probable connection between the verb to rob, and the noun robe, it may be mentioned that travelling luggage, which usually consists mainly of elothing, is popularly called butin by the French Canadians, plunder by the people of the western U.S.; and both words are not unfrequently employed in the same wide sense as the Italian roba, which is often applied to household- 
stuff, and, in fact, to almost all articles of personal property, as also, figuratively, to every thing connected with every day life. Story entitles his lively book on Rome, Roba di Roma, Roman matters.

P. 86. Rogue.-In the Romance of Walewein, Roges is the name of a knight magically transformed into a fox, Reynard.

\section{binnen dien es comen \\ จ. 5158
Die vos Roges ende heift vernomen \\ Waleweine in sijn vrijthof.}

A rogue is a cunning knave, and if this name had been commonly applied to the fox, it would suggest a possible etymology of our rogue. I do not, however, know any other instance of its use.

P. 114. Scabbard.-The derivation from scale-board, however plausible, is hardly to be reconciled with the O.E. scauberke and O.N. skálpr.

P. 123. Scissors.-Cantù, Sull' Origine della Lingua Italiana, p. 19, gives axicia as the name of this implement in the ancient lingua rustica, and this is probably the source of the modern cesoje, cesore.

Pp. 123-4. Sconse (2).-The ancient shield of Cornelius Scriblerus, when cleaned, proved to be " an old sconce." This was probably a metallic reflector placed behind a wall-lamp. The word may be the same as sconse, a dark lanthorn, but the change in meaning is remarkable.

P. 154. Sham.-The connection between shame and sham is illustrated by this passage from Nye, "Art of Gunnery," 1670 , p. 28 , where it seems to mean to disappoint, or deceive :-

"12. When Gunpowder is moist, or full of the earth of Saltpetre, it is naught to be shot out of great Ordnance, for it shameth the Gunner which useth it."

P. 175. Short.-This word, in the sense of brittle, as applied to iron, hot-short, cold-short, red-short, is evidently the same as the Swedish skör, Dan. skjor, which designate the quality of brittleness; and is possibly from the same root as short, in the ordinary meaning, In this combination, 
short is frequently pronounced, and sometimes written, sheer, as red-sheer iron, iron which is brittle when red hot.

P. 177. Shrewmouse.-The proposed etymology is rendered almost certain by a passage in Trevisa's "Higden," Polych. p. 335, new edition :-

" pere is grete plente of samon * * * and of vel schrevoed mys."

The Latin text has "mures nocentissimos;" the other old translation " most nyous mys."

P. 191. Sir, Sire.-Sior, used colloquially in many parts of Italy for signor, connects itself readily with that word on one side, and with Fr. sieur on the other. Sior, especially when compounded with the possessive pronoun, which would affect the accentuation, might easily pass into ser. The compounds Messer and Monsignore could hardly have originated in Italian, and the Fr. Messire and Monseigneur are historically older than the corresponding Italian words, which appear to have been introduced from France in the thirteenth century, when French was much used in Italy. Brunetto Latini, Canale, and Marco Polo all wrote in French, and they all use sire[s] and seignor[s], or seigneur [8] indifferently, often applying both to the same person, and sometimes in the same sentence. At the commencement of the first chapter of Marco Polo (Paris 1865), we have-"Messires Nicolas Pol, qui pères Monseigneur Marc estoit, et Messires Mafe, qui frères Messires Nicolas estoit." The oldest Italian translation of Marco Polo (Florence 1863), has Messer Matteo, Messere Nicolas, and Messer Marco.

The corresponding and contemporaneous Catalan form was Mossen, which could not have been formed from Gr. $\kappa v \rho$, and is evidently the same word as Fr. Monseigneur and Italian Messer.

In fact, so far are the mediæval Greeks from having bestowed their kvp on the Franks, that at the very period when such a thing was most probable, namely, during the French occupation of the Morea, they actually borrowed the French Messire, and used it as the honorary title of the French lords. See the Greek " Chronique de Romanie et de la 
Morée," published by Buchon, pp. 6, 7, 9, 33, 37, 38, and elsewhere.

Few words have undergone so many and so remarkable changes as the Latin senior. In France it has become seigneur, sieur, sire; in Italy, signor, sior, gnor, sciò, ser, and at Naples even si, as Si Pepe, Signor Giuseppe (Garibaldi), unless, indeed, we adopt the improbable supposition that the Neapolitan Si is the Arabic Si, Sidi; in Catalonia it has been docked at both ends, and curtailed to en, or, before a vowel, simply $n$, as En Pere, Nanfos ; in Castillian, Señor Pedro, Señor Alfonso; and, finally, in English, sire and sir.

P. 225. Smack (2).-The frequency of the application of the O.N. dreki, serpent, and other like words, to ships, leads one to suspect a connection between O.N. snekkja and snakr, a snake. Olaf Tryggvason's great ship was called Ormrinn langi, the long serpent.

A curious passage in an old Platt Deutsch chronicle suggests the possibility that smack was originally the denomination of a particular form of sail, and that the name was afterwards transferred to vessels rigged with such sails.

"Anno 1525 im Pasken segelde Herman Euers ersten mit enem bojer mit enem smaksegel in Engelant, dat do touorne vngehort was. Vnd des vorjars hadden se it erst darmede in Selant gewaget. Darna anno 27, 28 wageden se it mit smaksegel in Scotland, Norwegen, to Rige, to Dublin. Darna anno 31 in Island, darna anno 34 in Borwasie, dat touorne vngehort was." - Hamburgische Chroniken, 1861, p. 47.

P. 258. Soke.-This word must be the same as the O.N. $s \ddot{o} k$, which is connected, not with the verb at scekja, to seek, but with at saka. Sök signifies (1) an offence or injury which is a cause of action at law; and (2) a law-suit, etc., etc. It is true that at scekja sök is used for to pursue or prosecute an action at law, but the two words do not appear to be immediately related.

P. 265. To sound, to measure the depth of a cavity or fluid. No satisfactory etymology has yet been proposed for sound in this sense. May it not possibly be connected with O. Dutch tinten, tintelen, tenten, tentelen (Lat. tentare)? The 
dictionaries, Plantijn and Kilian, give only the surgical application of the word, but $I$ find it used for measuring the depth of water in Walewein, vv. 4975 and 4984.

Ic wille ooc tinten naden gront-

Daer tinte hi neder alte hant

Metten sohachte om den gront,

Die hem teerst was oncont.

P. 277. To spell (3).-Is not spell (spill) the ultimate element of the word, a letter, and merely another word for A.S. steef? If so, to spell, corresponds precisely to O.N. at stafa, and Ger. buchstabiren.

P. 279. Spick and span.-That in this expression spick is employed not in the sense of a splinter, but of a nail or spike fresh from the hammer, is rendered probable by the corresponding Ger. nagelneu, funkel-nagelneu.

P. 284. Spite.-The Danish spydig is certainly not connected with the Romance words cited, but comes directly from $S p y d$, a pointed weapon ; O.N. Spiót. Swift, in a Pastoral Dialogue between Dermot and Sheelah, uses spud for a "stubbed knife."

P. 303. To stain, distain.- Some doubt is thrown on the etymology proposed, by the O.N. at steina, to paint or colour, which occurs in the earliest age of Icelandic literature, and can hardly be from a Latin or Romance root. Besides, to stain is not to discharge an existing colour, but to superadd another. The O.N. at steina may be from steinn, a stone, because mineral substances were used in dyes and paints.

\section{WEDGWOOD, VOL. I.}

I submit also the following additions to my published notes on volume $I$.

P. 65. Artillery-The following citation, which I take from Tourtoulon, Jacme I., le Conquérant, Montpellier, 1863, vol. i. p. 287, is an interesting early example of the use of this word as a technical military term.

"Le mot artillerie (ars telorum) était en usage longtemps avant l'invention de la poudre à canon.

Artillerie est le charroi

Qui, par due, par comte, par roi, 
Ou par aucun seigneur de terre,

Est chargé de quarriaus en guerre,

D'arbalestes, de dars, de lances,

Et de targes d'unes semblances."

(Guillaume Guiart, poëte du XIIIe siècle)."

P. 7. Bait-In the phrase "to bait on the way," bait may very probably be connected with the Dutch beeten or bcten, to alight from a horse, mule, or carriage. This word is very common in Old Dutch, and is found in Kilian, but not in Teuthonista, or Plantijn. It has sorely gravelled Dutch etymologists, especially Ten Kate. See Melis Stoke, ii., 489, and particularly Müller, M. H. D. Wörterbuch, vol. i., p. 193, under erbeize.

Buckram.-See Müller, M. H. D. Wört. Buckeram. The authorities cited by me under this word, in the American edition of Wedgwood's first volume, still appear to me to show satisfactorily that, as first used in Central and Southern Europe, it signified a fine and costly tissue. In Germany, it seems to have had a different meaning. The form boqueranum suggests Fr. bouc as the root, if this stuff was of goat's hair. I am inclined to think that we have a confusion of two different words in this case.

I subjoin a few observations on obscure words in Chaucer, and in the poem of Cleanness, edited by Mr. Morris for the Early English Text Society.

Bidene.-To the observations of Huydecoper, Melis Stoke, breedere aantekeningen, i., 227, referred to in Hist, of the Engl. Lang., etc., p. 258, note, it may be added that indien, mettien, (met dien), door dien, nadien, which are precisely similar compounds, are of constant occurrence in old Dutch. See Sinte Christina, Bormans' notes, pp. 42 (indien), 235 (mettien), 257 (tien, te dien), 313 (binnen dien), 375 (nadien), 390 (van dien); see also Reinaert, (Willems), Glossary, bedi.

Bord, in

"Full ofte tyme he hadde the bord bygonne, Aboven alle naciouns in Pruce."

Prol. Cant. Tales, 1. 52-3. 
Is not bord or bourd, in this passage simply boort, buhurt, which occurs in a hundred forms in the sense of joust, or tournament, rather than table, as it is generally interpreted? "Ainc ne vous vi un boort commencer."

-Roman d'Aubri, Beк веR, fol. 71, quoted in Raynouard, Lexique, ii. p. 211.

I find in Warton (ed. 1840), vol. i., p. 174, note, a reference to Lydgate, Chron. Troy., b. ii., ch. 14, where to begin the bourd is said to mean to begin the tournament. We may fairly choose between the two meanings of bord or bourd, and certainly, in the case of a knight, tournament gives the better sense.

Courage or corage.-Rom. of the Rose, v. 22. For explanation and etymology of this word, which I have observed in no glossary, see American edition of Wedgwood, vol. $i$, under Courage; also, G. P. M's. Origin and Hist. of Engl. Lang., etc., p. 448.

Soone, in sense of early.-See Orig. and Hist. of E. L., pp. $447-48$.

"I nill be wroth, if that I may," Rom. of the R., v. 3098 . See note on p. 431 of Orig. and Hist. of E. L. To the instance from P. L. Courier may be added the following from the Dialogue entre Machiavel et Montesquieu, ou la politique de Machiavel au xix. siècle, Dial. viii., p. 94: "C'est à leurs droits civils que les peuples tiennent le plus: je n'y toucherai pas, si je puis." So, when the Man-in-the-Moon told Daniel O'Rourke to let go his hold of the sickle-handle by which he had hooked himself to the Moon, Dan replied: "The more you tell me to let go my hould, the more I won't, so I will!"

Dulcarnon.-See Orig. and Hist. Eng. Lang., p. 196, note. I supposed the etymology here suggested to be new, but I am told that it had been previously proposed by the editors of the new edition of Lord Bacon (Spedding).

Popering in the place.-Tale of Sir Thopas, Cant. Tales. -I never knew what to make of this, but have, I believe, found an explanation at last. Reading the old Flemish rhymed chronicle in Kausler, I found on p. 313, v. 9378,"Quamen te Poperinghen in den aert," 
which was evidently Popering in the place. Kausler (notes, p. 671) fumbles about the word aert, but comes to no result. Neither Teuthonista, Kilian, nor Plantijn help the matter. Applying, through a friend, to Altmeyer, whose Notices Hist. sur la Ville de Poperinghe gives no explanation, I was referred to De Vries, Middelnederlandsch Woordenboek, which I received soon after. On column 118, under Aert, fourth meaning, I find the word signified a market-place situated on a canal or river, also a slip, wharf, or landing-place for boats, and numerous examples are cited. Popering in the place, Popering in den aert, is then the town of Popering which grew up around such a market or landing place. Whether place is the common French place, used for a open market square, or a different word, is not clear; but I think it is place, with the same special meaning as is above given to aert ; for in Altmeyer, Notices Hist. sur la Ville de Poperinghe (Messager des Sciences Historiques de Belgique, 1840 ), p. $42-46$, is a long authorization in French to the town to make such slips or landing places, ès quelles plaches ara grés venans au riuage pour desquerkier et querkier les biens, denrées, etc. Elsewhere, mention is made of the " degrés des dites plaches," etc. The whole document is very curious. After all, it is about as probable that place, plache, is the Fr. plage, and in any event, the meaning of "Popering in the place" is clear.

Roquefort has plache: canal, ruisseau tiré d'une rivière, which might be as a slip or landing place; also, plache: Lieu ou s'assemblent ceux d'une même profession pour parler de leurs affaires.

The first plache may very well be plage, Lat. plaga; the latter, place, Lat. platea ; and as a landing place and a market place would be often the same thing, the two words have become one in form and in meaning.

Alabaunderrynes, Cleanness, in E.E. Allit. Poems, p. 81, v. 1470. The name of this stone is no doubt derived from the lapis Alabandicus of Pliny. I have not Pliny at hand, but, if I am not mistaken, he states that the lapis Alabandicus was used in the manufacture of glass, and it was therefore 
silicious. But, according to Laborde, Notice des Emaux, II $^{\text {me }}$ partie, ed. of 1853, p. 127, sub Alamandyne et Alabandine, the name was applied in the Middle Ages to an inferior species of ruby. See also Du Cange, sub Alamandince.

Penitotes, same poem v. 1472, is doubtless the peridot, and should probably be read Peritotes. See Laborde, p. 136, and Du Cange, sub Peritot.

Pynkardine, do., do. May we not read Perre carnadine, carnelian stone?

\section{XIV.-ON THE WORD RÜNHENDA OR RIMHENDA,}

AND THE INTRODUCTION OF RHYME INTO ICE-

LAND. By Guðbrandr Vigfusson, Eso.

Is the circular or notice of papers for this month, it was announced, as I at first intended, that I should give you a paper upon words introduced from Anglo-Saxon, and imported into Iceland, in early times. I must, therefore, beg your forbearance for converting the plural into a singular, and discussing only a single word, and that not of undivided A.S. origin, but, as will be seen, rather having England as a medium or channel, through which not only a new word, but also a new kind of metre, came into " ultima Thule." In doing so, I propose to give you short pleasure, instead of the long pain of listening to a protracted series of often uncouth words. I also confess my uneasiness at going too closely now into these topics, as the matter is by no means always clear, and needs long deductions which would by far exceed the short space of an evening, and yet neither be exhausting nor satisfactory. A language with so enormously rich a vocabulary as the Icelandic, extending over a period of nearly a thousand years, still living and vigorous, must be taken by divisions, not in bulk.

I have chosen as my theme the origination of one kind of metre, the so-called Rinhenda,-small and insignificant in its origin, but bringing with it a principle which, in the course of centuries, has changed the aspect of a great part of modern poetry, when compared with the ancient. Iceland 